\title{
A Study on the Relationship between Organizational Culture and Organizational Performance and a Model Suggestion
}

\author{
Ebru Yildiz \\ Sakarya University, Institute of Social Sciences
}

\begin{abstract}
Organizational culture is defined as set of goals and values shared by employees in the organization. Recently it has also come to be perceived as a resource of knowledge in the organization. In the literature, along with the studies aiming at identifying the elements of organizational culture, there are some research that study the relationship between organizational culture and performance. This article is a theoretical study of the two concepts and suggests a research model for further research. Recently, knowledge management and innovation strategy have started to be regarded as features of organizational culture. Research shows that these two variables also have significant impacts on organizational performance. Our model suggests measuring the effect of organizational culture on performance along with the supportive impacts of knowledge management and innovation strategy.
\end{abstract}

Keywords: Business; Culture; Performance; Organization

\section{Introduction}

Although there is not a generally accepted definition, organizational culture is defined as a concept that orients employees, guides them in their behavior and communication, and shows the character of the organization. Multiple dimensions of the concept of organizational culture have been examined in the literature and the relationship between organizational culture and organizational performance has drawn the attention of researchers and become a popular subject matter. However, the basic problem in the literature is the difficulty of defining the variables that express both concepts.

The relationship between organizational culture and organizational performance is a significant subject in Strategic Human Resource Management. In today's world organizational culture is basically built on increasing competition at the national and international level, ever-changing exogenous factors, and recent developments in information and communication technologies, values and practices and has become one of the research fields of strategic human resources with its impact on measurable performance. The subject itself is significant not only at an academic level but also in practice. Researchers and practitioners devote significant time and effort to the subject of organizational cultures due to factors such as investment by entrepreneurs and top management on employee development, efforts to sustain the organization in an environment of harsh competition and pressure from interest groups for ever-increasing performance. However, organizational culture is a multi-dimensional concept and performance is shaped by various criteria. Hence, research in this field should be carried out with more meticulous modeling. Most of the research that exists in the literature has investigated the relationship between organizational culture and organizational performance which is appraised by financial criteria only. At this crucial point, two concepts which are significant for strategic human resources management should be included in the evaluation - knowledge management and innovation.

Knowledge management is an approach to adding or creating value by leveraging the know-how and expertise resided in individual minds. Practices of knowledge management influence the relationship between strategic human resources and innovation performance (Chen and Huang, 2009: 105). The dimensions associated with performance are 
acquisition and exchange of knowledge. Research suggests that an organization that invests in training and development programs, encouraging employees to improve and refresh their skills and expertise, can achieve higher levels of employee participation and hence higher levels of performance.

Managers who have recently come to see the importance of innovative idea generation, rewarding generated ideas and of entailing the development of new products or services as well as new administrative systems, have also started to prioritize the subject of organizational culture. As a result, the concept of Strategic Human Resource Management has gained new dimensions thanks to knowledge management and innovativeness approach. An organization could gain a competitive edge and increase its existing value through adapting such strategy and approach.

Financial criteria which have been widely employed compared to other performance criteria could be shaped by impacts from other factors. If we are to establish a cause and effect relationship, it can be argued that many factors that have an impact on performance could be included in the model as direct or indirect variable. Therefore, although financial criteria are of significance, other organizational behavior management variables that are important in terms of Strategic Human Resource Management should be regarded as performance criteria. Such an approach would contribute to the literature to a great extent.

The present study examines the nature of the relationship between organizational culture and organizational performance and suggests a research model.

\section{Organizational Culture}

The concept of organizational culture entered the literature with an article in Administrative Science Quarterly published in 1979 (Hofstede et.al., 1990: 286).

It was then developed as a concept by the business management authors in the United States. The concept of organizational culture secured its place in management science thanks to the works of many researchers. Katz and Kahn with "The Social Psychology of Organizations" and Deal and Kennedy with "Corporate Culture" among others pioneered in this front (Arslan, 2004: 216).

Although organizational culture is one of the most popular subject matters in management and organization theory literature, there is no consensus on its definition and scope. According to Ogbonna and Harris (2000: 769), widespread disagreement on the definition and scope of the organizational culture concept stems from the following reasons:

Treating culture as a unitary concept reduces its value as an analytic tool.

Culture cannot be equated to power, politics or climate.

There has not been a consensus on whether organizational culture can be easily changed.

Edgar Schein defines organizational culture as "series of basic assumptions a group makes in a specific order in order to solve the issues of external adaption and internal integration" (Eren, 2010: 135).

According to Robbins (1983), although culture has traditionally been viewed as one facet of anthropology, classifying organizational culture as purely anthropological is somehow a too narrow approach, as it emerged as an interdisciplinary phenomenon with contributions from psychology, sociology, anthropology and social psychology (Corbett and Rastrick, 2000: 15).

Hofstede (1997) defines culture as the collective programming of the mind, distinguishing the members of one group or category of people from others. According to him, national and organizational cultures are phenomena of different structures. At the national level, cultural differences reside in values, while, at the organizational level, they reside in practices (de Hilal et.al., 2009: 101).

Moreover, practices are the visible parts of culture, whereas values are the invisible parts. Therefore, practices are subject to planned change, whereas values, although they do change, they cannot be subject to planned change (de Hilal et.al., 2009: 101). 
Ferraro (1998), defines organizational culture as everything that people have, think and do as members of their society (Tseng, 2010: 270). Organizational culture is a concept that represents the character of an organization, which directs employees in their daily working relationships and guides them on how to behave and communicate within the organization. As well as manifesting in an organizations' structure (Ribiere and Sitar, 2003 cited in Tseng, 2010: 270). Aidla and Vadi (2007: 5) it defines organizational culture as an important factor that influences the performance of an organization.

Jones et.al. (2005) have demonstrated that organizational culture is a source of knowledge since it enables employees to create, acquire, share and manage knowledge. Organizational culture has a strong bond with the competitive performance of a company. Some authors agree that performance comes from interdependent behavior like cooperation, knowledge sharing and mutual assistance (Tseng, 2010: 272).

Almost all definitions of organizational culture express the sets of goal and values members of that culture possess. Furthermore, the meanings and values that constitute organizational structure are based on symbols, behaviors and structures held by organization members (Fisher, 1997 cited in de Hilal et.al., 2009: 101).

Organizational culture represents a perception that organization members have. However, this does not mean that subcultures cannot be developed within an organization. Large organizations have one dominant culture together with many subcultures. Dominant culture corresponds to common values shared by the majority of the organizations' members. The culture of an organization denotes the dominant culture of an organization (Robbins, 1994: 302 cited in Arslan, 2004: 218).

Onken (1999) examines temporal elements of organizational culture. The three temporal elements within this framework are polychronicity, speed and hyper competition. Polychronicity denotes a situation where employees perform more than one task at a time. The speed element demonstrates how quickly decisions are made in an organization. Onken describes hypercompetitive behavior as the organizational structure that continuously generates new competitive advantages as well as destroying, obsoleting or neutralizing the opponent's competitive advantage, thereby creating disequilibrium, destroying perfect competition, and disrupting the status quo of the marketplace (Onken, 1999: 233). Onken uses financial criteria as performance measures and suggests that more polychronicity and higher speed lead to higher firm performance (Onken, 1999: 240).

Organizational culture is the sum of individuals' cognitive perceptions that are developed in relation to individuals' experience and character and also the interaction of both, as well as the processes and events followed by the organization, including individuals' perceptions of workplace and of their own job. "Poorly performing employees, poor work quality, low levels of loyalty to the organization, high levels of absenteeism and employee turnover rate, alcoholism, stress and a bad day" are the manifestations of a problematic organizational culture (Fletcher and Jones, 1992).

Criteria that are significant in terms of culture in an organization are appraised both in the short and long term. Felt work load, limits of an employee's authority, clearly defined job definitions, inter-employee relationships, feedback, team work and support, felt levels of openness and efficiency of work objectives are among the criteria which are usually appraised in the short term. On the other hand, long-term orientation dimension deals with factors such as loyalty and morale, felt effectiveness of training programs, career development and felt service quality. These dimensions serve to examine organizations in terms of four general bipolar descriptive types: These dimensions are (Fletcher and Jones, 1992):

i. Homogeneous vs. Heterogeneous Culture

ii. Enriched vs. Managed Culture

iii. Developing vs. Stationary Culture

iv. Balanced vs. Dissonant Culture

It is Fletcher and Jones' (1992) opinion that such classification of organizations would be useful. For example, according to the authors, an organization can be homogeneous, managed, stationary and balanced at the same time; 
however, generating a formula of an "ideal culture" can be misleading since ideal culture may vary depending on the situations.

Organizational culture also reflects how it is perceived by the external entities, its values and social standards, as well as its relationship forms and levels with other organizations and individuals. Therefore, culture with such a function, is one of the most significant tools of an organization which serves to tie organization to society and identify the place, importance and even success of the organization in relation to society. Each organizational culture carries the influences of the social culture and of other organizational cultures it interacts with, hence being continuously shaped by them. Culture does not come into conflict with the society. If a new culture is in harmony with the norms and values of the society, it could significantly contribute to that society (Eren, 2010: 136).

\section{Characteristics of Organizational Culture}

Eren (2010: 138) describes four characteristics of organizational culture:

Organizational culture is a learned or acquired phenomenon. Organizational culture should be shared by the group members. Organizational culture is not in the written text format. Organizational culture exists in the mindset, consciousness and mind of the group members as beliefs and values.

Organizational culture reveals itself as steady repetitive or emerging behavioral patterns.

Robbins and Judge (2011: 554) examines seven basic characteristics of organizational culture. These are:

Innovation and risk taking: The extent employees are being supported in innovation and taking risk;

Attention to detail: The extent employees pay attention to the obvious details;

Outcome orientation: The extent the management focuses on the results rather than the procedures,

People orientation: The extent the management considers the impact of the results on the employees in the organizations,

Team orientation: The extent employees can work as a team rather than acting individually,

Aggressiveness: The extent employees are entrepreneurial and competitive,

Stability: The extent organizational activities are oriented towards preserving and developing the status quo.

The seven characteristics defined above define the organizational culture. The cultural structure that emerges sets the foundation for the shared feelings, how tasks should be performed in the organization and mode of doing business (Robbins and Judge, 2011: 554-555).

\subsection{Elements of Organizational Culture}

Basic elements of organizational culture would be values, norms and assumptions (Guclu, 2003: 150).

Values

Values define what is "good and bad," hence they are closely related to the ideals shared by members of a group. Values give us a feeling of "this is how I aspire or desire to behave" (Trompenaars and Hampden-Turner, 1998: 22).

Norms

Norms are common expressions that demonstrate what is right and what is wrong (Trompenaars and Hampden-Turner, 1998: 21). Norms can develop on a formal level as written laws, and on an informal level as social control. Consciously or subconsciously, norms give us a feeling of "this is how I normally should behave" (Trompenaars and Hampden-Turner, 1998: 22).

\section{Assumptions}


Assumptions are usually unconscious principles that form the reference framework for how individuals or groups act, think and feel. The difference between this system of principles and the system of values is the naturally accepted dominance of the former in a cultural form which renders comparison with any other option impossible. Therefore, assumptions are employed as the reference framework for the perception of reality. Assumptions direct the value, belief and norm system of a culture (Bozkurt, 1996: 91 cited in Iscan and Timuroglu, 2007: 122).

Motivated group members, who are involved in deep self-analyses, can search assumptions through deeper observations and more focused questions. When some of these assumptions are well understood, it would be easier to decipher the subtle meanings of several behavioral and man-made incidents that are observed. Furthermore, an understanding of deeply embedded, taken-for-granted behaviors would enable us to see how ambiguous or selfopposite cultures may seem (Schein, 2002: 9).

Ceremonies, rituals, customs, stories, myths, symbols, languages and heroes are among the visible forms of expressions in organizational culture (Guclu, 2003: 150).

\section{Ceremonies and Rituals}

Ceremonies are planned activities for a group of people who convene for a special event. Such activities serve the purpose of emphasizing the success of people who have served the organization perfectly. Thus, while such people are rewarded, they also set good examples to others (Eren, 2010: 138).

Ceremonies are special events in order to memorize the values of an organization. Through several ceremonies, organizations try to sustain the existence of their cultures (Ozen Kutanis, 2010: 7).

\section{Customs}

Customs are repetitive sequences of activities which express and reinforce the key values of the organization such as what goals are most important, and which employees are most important (Robbins and Judge, 2011: 565).

Stories

Stories circulate among the employees in organizations and include narratives such as rags-to-riches, reductions in the work force, and reactions to past mistakes. Stories anchor the present in the past, explain and legitimate current practices (Robbins and Judge, 2011: 565).

Myths

A myth is a means of communication which establishes the values or identification systems of a social group or an organization. When interesting incidents and stories about the values, founders and members of an organization at different hierarchical levels turn into a message to convey a certain meaning, they become myths. Myths may have both positive and negative meanings. Myths are regarded as positive when they create an environment of sharing, or reinforce the sense of belonging to the organization, whereas they are regarded as negative when they cause grouping against the organization hence reinforcing the separation (Guclu, 2003: 153-154).

Symbols

Executives' offices, the size of offices, office furniture, the types of automobiles executives are given, means of transportation for business travels and attire are all examples of symbols in an organization (Robbins and Judge, 2011: $565)$.

Symbols conveys to employees who is important, the degree of egalitarianism top management wishes, and the kinds of behaviors that are favored such as risk taking, participation or individualism (Robbins and Judge, 2011: 565).

\section{Language}

Employees within organizations use language to identify the culture of the organization as well as to accept and help preserve it. Unique terms are used to identify suppliers, clients and key individuals. Hence, new employees have to become familiar with the dominant language and jargon of the organization (Robbins and Judge, 2011: 566). 
Heroes

Heroes are very successful individuals who have become known in an organization with the services they rendered, well carried out the role the organizational culture dictates, hence setting example for the organizations (Eren, 2010: 137).

\subsection{Benefits of Organizational Culture}

Benefits of the organizational culture for top management and employees are as follows (Eren, 2000: 152-153; Simsek et.al., 1998: 30-31; Ozdevecioglu, 1995: 125-126; Ataman, 1995: 70 cited in Sahin, 2010: 25-26):

The organizational culture helps employees better understand certain standards, norms and values, hence become decisive and consistent in the pursuit of success and work in harmony with their executives.

The organizational culture standardizes and rationalizes modes and processes of doing business, hence positively influencing employee psychology and morale and increasing organizational efficiency.

The organizational culture contributes to the emergence of new executives from within the organization.

On the condition that the organizational culture enables a wide consensus, it can prevent intra-organizational factions.

The organizational culture plays a critical role in organizational communication and interactions between individuals. The organizational culture contributes to the development of the sense of "us" and team spirit, hence it positively impacts organizational climate.

Conflicts may arise within organizations for several reasons. These conflicts can be rationalized and neutralized through certain standard practices and procedures developed within the organizational culture.

The organizational culture perpetuates organizational life by circulating itself among generations through symbols, ceremonies, heroes, slogans and stories. In a nutshell, the organizational culture contributes to the continuity of the organization.

Culture is like an identification card. Evaluations about an organization or an institution are made by reference to their culture.

\section{Organizational Performance}

Organizational performance as a concept is defined with different variables in literature. Financial variables or concepts from human resources management are used to assess the performance of organizations. Scholars often use the terminology organizational "effectiveness" and organizational performance interchangeably to describe the same phenomenon (Selden and Sowa, 2004; Seashore and Yutchman, 1967; Steers, 1976; Denison and Mishra 1995; Quinn and Camoson, 1983; Lewin and Minton, 1986 cited in Uzun, 2007: 94).

Georgopulos ve Tanenbaum (1957) defined organizational performance as "the extent to which the organizations which have certain sources and means fulfill their objectives exploiting overlapping capacity without creating further burden for employees" (Uzun, 2007: 94).

Questions such as what kind of objectives organizations have, which measures should be used for the evaluation of these objectives, and how a comprehensive evaluation should be carried out caused theoretical understandings of the concept.

According to Steers (1976), the concept of organizational performance brings along the following problems (Uzun, 2007: 94). 
1. The concept of organizational performance itself (abstract/tangible)

2. The evaluation criteria are relatively unstable over time (growth/shrinkage periods)

3. Interrelation of the evaluation criteria (positive/negative)

4. Measurement means to be used in the evaluation (reliability/validity)

5. Relevance of the evaluation criteria to the organizational objectives and characteristics

6. Contribution of the evaluation criteria in comprehension of organizational dynamics

7. Level of analysis while evaluating the performance (organization-wide/individual)

A thorough examination of the problems related to organizational performance suggests that describing evaluation criteria necessary for performance measurement involves significant decisions. Above all, the subject matter of performance is "human". Results such as contributions of training programs which employees enrolled in, as well as reflections of a democratic management style are abstract concepts that are difficult to measure. Research suggests that financial criteria are mostly used as evaluation standard in the literature. However, the performance of an organization cannot be captured through a single construct, namely financial values. For example, which variables would be employed to measure non-financial outputs such as knowledge sharing among employees, innovative ideas, and outputs of a suggestion system which has become more and more significant through years?

Furthermore, factors outside an organization also have an impact on the performance. A crisis, competitors' unforeseen strategies, ever-changing market conditions are all exogenous factors that may directly have an impact on the planned performance level. It would be wrong to have measurement or set targets without considering these factors.

The level of analysis while evaluating performance is also problematic. It is not easy to draw a clear line between individual and organization-wide performance. It can be expected that employees who increase their individual performance will eventually contribute to the increase of organizational performance. However, this may not always be the case. As mentioned above, exogenous factors may prevent organizations from reaching set targets.

In a nutshell, developing more comprehensive perspective in evaluation of organizational performance through a consideration of changing conditions and a selection of criteria suitable for organizational structure can minimize the aforementioned problems. Following points that are widely accepted by the researchers also supports our suggestion.

\section{Approaches and Models for Organizational Performance}

Despite the existence of mentioned problems, Cameron (1986) notes that there is a consensus about the following points regarding organizational performance (Uzun, 2007: 97):

Though being vague and complicated, the subject matter of organizational performance is an important subject of organizational science.

Since it is almost impossible to conceptualize an organization, it is also impossible to conceptualize an effective organization.

It is impossible to acquire the best and the most proper performance indicators. Criteria are dependent on individual values and choices.

Different organizational performance approaches can be suitable for different situations depending on the objective of organizational performance survey, its obligations and limitations.

The essential problem related to the area of organizational performance is a problem of criteria but not theory.

In the lights of these evaluations, four different kinds of organizational performance approaches are prevalent in the literature (Uzun, 2007: 97-98):

Goal Model (Achievement of Goals): The objective of this model is to measure whether goals are achieved or not.

Open Systems Model: The objective of this model is to measure how resources are acquired. 
Multiple Constituencies Model: The objective of this model is to measure whether the needs of different interest groups are met or not.

Balanced Scorecard Model: "Balanced scorecard makes it possible to see performance in different areas at the same time and evaluate how these processes evolve as well as their outcomes. This model consists of performance evaluation in four areas:

i. Financial perspective,

ii. Customer perspective,

iii. Internal processes,

iv. Learning and innovation perspective" (Uzun, 2007: 99).

Literature suggests many more models for performance evaluation developed in parallel to the above mentioned approaches. Cunningham (1976) mentions seven different models (Uzun, 2007: 100):

i. Rational Goal Model: Ability of the organizational model to realize the objectives of the organization.

ii. Systems Resource Model: Ability of the organization to create resources.

iii. Managerial Process Model: Ability of the organization to carry out functions such as planning, budgeting, and decision making.

iv. Organizational Development Model: Competency of an organization in problem solving.

v. Bargaining Model: Bargaining power of the organization to acquire scarce resources.

vi. Structural Functional Model: Improvement capacity of the organization in order for self-protection and guarantee.

vii. Functional Model: Ability of the organization to perform socially beneficial activities.

Cameron (1986) on the other hand examines seven organizational performance model (Uzun 2007: 100).

i. Goal Approach, the capacity to realize the organizational objectives,

ii. System Resource Approach, the ability to exploit resources efficiently,

iii. Process Approach, the ability to perform the activities smoothly,

iv. Strategic Constituency Approach, the level of satisfaction of the main stakeholders,

v. Legitimacy Approach, the level of legitimacy in society,

vi. Ineffectiveness Approach, the level of no fault,

vii. High Performance Systems Model, advance among the similar organizations.

Review of approaches and models regarding organizational performance suggest significant common points. For example, the capacity to realize the organizational objectives is the leading one. Identification of clear and measurable objectives is the most significant task. Objectives should also be set according to the conditions of competition, economic situation and existing competency, ability and know-how of the human resources of the organization. Otherwise, unfulfilled objectives will be a source of pressure and stress among the employees, hence negatively impacting the entirety of the organization.

Another significant point is the strategies and utilization of resources in the realization of objectives. Efficient and effective use of all organizational resources is of high significance in the organizational performance management. Therefore, strategies should be identified and followed in the same manner.

On the other hand, satisfaction level of the main stakeholders such as employers, clients and employees are also highly important. Evaluation of satisfaction level of these stakeholders should be performed by employing both quantitative and qualitative criteria. These criteria includes variables such as profitability, return on investment, product/service quality, level of knowledge sharing among employees, loyalty, and corporate reputation, etc. 


\subsection{Performance Criteria}

Criteria which will be employed in organizational performance measurement depend on the definition of performance. This subject is effective both at individual and organizational level. Human resources management should adopt the "strategic" approach and then direct top management for the most suitable organization-wide performance management. Starting from the traditional approach, human resources management should also define precise performance criteria both on the level of employees and also organization-wide.

Adapted from the research done by Campbell (1977), Robbins and Barnwell (2002) developed the performance criteria shown in Table 1 (Uzun, 2007: 95).

Table 1: Organizational Performance Criteria

\begin{tabular}{|l|l|l|}
\hline 1. Total effectiveness & 11. Motivation & 21. Technical abilities of executives \\
\hline 2. Efficiency & 12. Morale & $\begin{array}{l}\text { 22. Information management and } \\
\text { communication }\end{array}$ \\
\hline 3. Productivity & 13. Control & 23. Preparedness \\
\hline 4. Profit & 14. Conflict & 24. Utilization of environment \\
\hline 5. Quality & 15. Planning and objective setting & 25. Evaluations by externals \\
\hline 6. Occupational accidents & 16. Flexibility / Adaptation & 26. Stability / Determination \\
\hline 7. Growth & 17. Goal consensus & 27. Value of human resources \\
\hline 8. Absenteeism & 18. Harmony between role and norm & 28. Sharing of participation and authority \\
\hline 9. Employee turnover rates & $\begin{array}{l}\text { 19. Internalization of organizational } \\
\text { objectives }\end{array}$ & $\begin{array}{l}\text { 29. Importance attached to training and } \\
\text { development }\end{array}$ \\
\hline 10. Job satisfaction & 20. Social abilities of executives & 30. Importance attached to success \\
\hline
\end{tabular}

Source: Robbins and Barnwell, 2002 cited in Uzun, 2007: 95.

A close review of the criteria in Table 1 suggests that organizational behavior criteria and other criteria which are related to the relationship between the organization and its environment are also crucial along with the financial factors. Therefore, selection of the criteria in the research regarding the evolution of organizational performance is a significant task.

Aluko (2003), in his research where he examines the impact of culture on organizational performance and measures it against the ability of the organization to meet the needs of three main stakeholders, namely owners, employees and customers. He defines the criteria as follows (Aluko, 2003: 173):

i. Owners' satisfaction with profits or other financial returns,

ii. Employees' satisfaction with the conditions of work, such as wages and remuneration, style of supervision, rapid promotion and the ability of the organization to guarantee job security,

iii. Employees' desire to stay with the organization,

iv. Customers' satisfaction with the quality of the products of the organization.

Germain et.al. (2001), states that performance control can be of two types (Tseng, 2010: 272).

i. Internal performance: Costs, product quality, and profit levels.

ii. Benchmarked performance: Comparing costs, quality, customer satisfaction, and operations to a benchmark of the industry or its leaders.

Chakravarthy (1986) finds that classic financial measures such as return on equity, return on sales and return on investment are incapable of distinguishing the differences in performance between firms. Such criteria are not to identify the performance about organizational development and innovation (Tseng, 2010: 272). Edvinsson et.al. (1997), Lee et.al. (2005) point out that non-financial measures such as customers, investors, and stakeholders have become increasingly important (Tseng, 2010: 272). 
The following problems have been emphasized regarding the indicators used to measure organizational performance (de Hilal et.al., 2009: 102).

i. Lack of correlation between the chosen indicators and the performance dimensions,

ii. Lack of correspondence between managerial practices and the results measured by the chosen indicators,

iii. Subjectivity of the chosen indicators.

\subsection{Possible Mistakes in Performance Evaluation}

Mistakes are not uncommon in the performance evaluation. Possible mistakes make it difficult to differentiate between high performing and low performing employees. Many mistakes can happen regardless of the technique or system utilized for performance evaluation (Barutcugil, 2002: 229).

Significant ones can be listed as follows:

i. Opinion against Evaluation: The most significant question in evaluation systems is that prejudices, be them positive or negative, have an impact on the system. Some members of top management can be against evaluation systems and insist that such systems do not have any return for the organization. In some other organizations; top management and employees may not like evaluation systems. Therefore, evaluators may have difficulties in conveying information that may help identify the performance levels of different employees, hence cannot make decisions (Barutcugil, 2002: 229).

ii. Problems Related to Design and Execution of System: Poorly designed evaluation systems can have useless and ineffective outcomes for those involved. Criteria which will be used for performance evaluation are crucial. It is of crucial importance to select the right criteria for performance evaluation and to identify the importance level of these criteria (Barutcugil, 2002: 230).

iii. Problems Related to Evaluator; although the performance evaluation system is well designed, some problems may arise because of inadequately trained evaluators (Barutcugil, 2002: 230).

One of the most significant problems in performance evaluation is the halo effect, which is defined as a cognitive bias in which one's judgments of a person's character or an event can be influenced by one's overall impression of him or her or of other events. Let's suppose that a manager evaluates a group of employees as "unsuccessful" or "inefficient" after an unpleasant incident. If these employees engage in efforts to change the perception of the manager and fail, or give up any effort with the opinion that manager's established perception of the employees will never change, this will have a negative impact on the performance. Low performance eventually will deteriorate the relationship between management and employees, hence deteriorating overall organizational performance.

Another severe rating error in performance appraisal is known as contrast effect. When supervisors rate employees one after another, rating of an exceptional performer could affect the subsequent ratings of other individual(s) (Barutcugil, 2002: 232).

Individual choices as well as prejudices could also affect performance appraisal. Individual choices, race, gender, age or whether the raters like the employee or not, often cause the raters to make significant errors in judgment (Barutcugil, 2002: 232).

As can be seen, rating errors in performance appraisals could result in a negative cultural structure. Such a negative cultural structure could have a deteriorating impact on organizational performance, which will eventually lead to poor employee performance. Poorly performing employees could reinforce already negative culture. Even new employees would be influenced by a negative organizational culture. 


\section{Relationship between Organizational Culture and Organizational Performance}

While there are numerous articles related to the nature and definitions of culture, relatively fewer articles have contributed towards culture and performance research. The reason for this is the difficulty of analyzing culture (Lee and $\mathrm{Yu}, 2004: 340)$.

There are two approaches in the literature which investigate the possible relationships between corporate culture and organizational performance (Kilic, 2009: 83-84):

i. Kotter and Heskett's Approach

ii. Deal and Kennedy's Approach

According to Kotter and Heskett's discussion, it is assumed that the organization forms uniformity with strong stakeholders, clients and employees. Systems of shared values within the organization help sustain high performance culture.

According to Deal and Kennedy's approach, strong culture can have a major impact on the success of the business since it makes it easy for organizations to learn from past successes and failures.

Yuksel (2002: 66) notes that there are a few assumptions regarding the basis of a relationship between a strong culture and performance.

i. Goal consensus

ii. Motivation

iii. Self-control

A superior performance is achieved if employees' focus is on the same objective and if they choose supplementary activities in order to achieve the same objective. Higher motivation could also yield the same results. Moreover, selfcontrol, which results in smooth flow of day-to-day works, instead of control forced by a bureaucratic structure also has a positive impact on performance.

Daulatram (2003: 222), concluded that strong organizational culture increases overall job satisfaction, which in turn increases efficiency, hence enhancing organization-wide performance.

Kilic (2009: 95) describes eight effects organizational culture has on performance:

i. Communication effect

ii. Decision making effect

iii. Trust effect

iv. Stress effect

v. Conflict effect

vi. Alienation effect

vii. Motivation effect

viii. Organizational change effect

Strong communication has a reciprocal impact on other elements and increases performance (Kilic, 2009: 95). Furthermore, inclusion of employees in decision-making mechanisms raises respectability and employee satisfaction, hence enhancing performance.

In the same manner, high levels of trust also reinforce loyalty and enhance performance.

There are opposing views regarding stress effect. One view argues that there is a direct proportional relationship between stress and performance, while another argues that there is an inversely proportional relationship between the two. A third view describes the relationship between "stress and performance as an upside down U shaped curve. Individuals under low levels of stress lack stimulus strength necessary for a higher performance. In the same manner, 
individuals under high levels of stress would spend their energies on coping with stress instead of focusing on increasing their performance. Performance is high under normal levels of stress" (Kilic, 2009: 101).

There are also two opposing views regarding conflict. According to one view, conflict has a negative impact on performance, while another argues that reasonable levels of conflict would have a positive impact on performance.

While there is an inversely proportional relation between alienation and performance, there is a consensus about the positive impact of motivation on performance.

Cetin (2004: 65) points out the positive impact of organizational change on performance in the long run.

Denison (1996) argued that many researchers were limited by the artificial paradigm separation between climate and culture research and that climate research was associated with surveys and statistical analysis while culture research was usually done through qualitative field studies. According to him, climate and culture research studies are frequent investigations of different manifestations of the same construct (Lee and Yu, 2004: 341).

Blunt and Jones (1992), George and Jones (1996) and Zakaria (1997) argued that all organizations function within a specific culture, and that managers and other practitioners have to understand their cultural settings if their organizations are to perform effectively (Aluko, 2003: 166).

One of the earliest studies investigating the relationship between organizational culture and organizational performance was carried out by Peters and Waterman (1982) and they reported a significant link between a particular type of strong culture and superior financial performance. After them, Kotter and Heskett (1992) also proved the existence of a similar relationship. In their study, the authors found that the content (type) of culture is the impact that adaptive culture has on performance (Prajogo and McDermott, 2011: 713).

Literature on organizational culture commonly focuses on two major aspects of culture: content, which signifies the types of values and behaviors held by employees, and strength or the depth of those behaviors embedded among the employees. Both content and strength of culture are important factors for achieving a high level of performance (Kotter and Heskett, 1992; Sorensen, 2002 cited in Prajogo and McDermott, 2011: 714).

Furthermore, the relationship between culture and innovation has also been investigated in the literature (Kanter, 1983; Brannen, 1991; Ahmed, 1998; Conceiçao et.al., 2002; McLean, 2005 cited in Prajogo and McDermott, 2011: 714). The term innovation in this context has been defined as something that is "new" or "improved" to create significantly added value either for the company or its customers. And organizational culture has eventually been shown to be a key determinant (Prajogo and McDermott, 2011: 714).

In Gordon's (1991) view, different industries have developed different cultural models and financial rewards may differ given the objective of stressing short or long term performance. The way a company is organized and how people operate within the structure are strongly determined by its culture. Thus, culture, he concludes, is a key variable that affects performance (de Hilal et.al., 2009: 102).

The impact of organizational culture on organizational performance has been well documented with emphasis on customers, employees and environment by Ozen Kutanis and Mesci (2010) in a study carried out on full time employees of a five star hotel chain.

Alchian and Demesetz (1972) showed that the results achieved by an organization derive from the efforts of several agents, such as shareholders, managers and employees. Since performance indicators signal the results, performance is the output shaped by these agents (de Hilal et.al., 2009: 102).

Denison (1984) found that two indices, "organization of work" and "decision making", were found to be significantly correlated with financial performance in a study carried out with a convenient sample of 34 firms representing 25 different industries. In addition, he found that the strength of the culture was predictive of short-term performance, when performance was defined with broad indicators like return on assets, return on investment and return on sales (Lee and Yu, 2004: 342). 
Gordon and DiTomaso (1992) found that a strong culture was predictive of short-term company performance. They found that 'adaptability' as a significant cultural value which was associated with stronger performance both in the short and long term (Lee and Yu, 2004: 342).

Kotter and Heskett (1992) reported that there was a relationship between the strength of the corporate culture and organizational performance in the short term, but it was not a strong one. There could be poorly performing firms despite strong organizational culture, or the opposite could also be valid (Lee and $\mathrm{Yu}, 2004: 343$ ).

In explaining performance, Hensen and Wernerfelt (1989) found that organizational factors (importance attached to human resources and to achieving goal) are twice more effective than economic factors (market share, relative market share, profitability and size of the firm) (Uzun, 2007: 106).

In a study carried out for developing a model for the relationship between organizational culture and organizational performance, Marcoulides and Heck (1993) used criteria such as sales, profit, market share and active profitability as performance measures and reported that organizational culture variables are determinants in organizational performance (Uzun, 2007: 107).

According to Sorensen (2002), continuity and performance is usually a function of the organization in economies where exogenous factors are relatively stable. "Organizational culture in an ever changing environment has the ability to rearrange everyday functioning of the organization in order to adapt to changing conditions" (Kilic, 2007: 98).

Jayaram, Droge, Vickery (1999: 1-20) examined human resource management practices that affect performance in manufacturing firms and documented that practices such as top management commitment, communication of goals to employees, employee training, and cross functional teams are key factors affecting organizational performance. Rodgers and Hunter (1991) showed that when top management commitment to specific performance objectives was high, firms experienced an average gain in productivity of 56\%. As opposed to this, when top management commitment to organizational objectives was low, the average gain in productivity was only 6\% (Jayaram et.al., 1999: 3). Jayaram et.al. (1999: 4), they emphasized the impact of communication of goals, employee training and development practices and building cross functional teams as well as the relationship between these and quality performance. Finally, authors, mentioning research by Dreyfus and Vineyard (1996) pointed out that findings of a survey of 747 managers of manufacturing firms show a link between training and development programs and productivity growth; also that Kinnie and Staughton's (1991) study carried out in 7 manufacturing firms, demonstrated that quality related employee training facilitates the effective use of advanced manufacturing technologies.

Variables mentioned above give us clues about the elements of organizational culture. Organizational performance is directly and positively affected by the climate of an organization which is goal oriented, with a participative culture and encouraging team work.

In a study carried out in banking industry, Karayalcin (2009: 98) demonstrated that competitive and bureaucratic organization types do not have meaningful impact on the organizational performance whereas innovative and communitarian organization types have meaningful impact on it.

Lim (1995: 20) examined studies on the relationship between organizational performance and culture and pointed out that a major obstacle in these studies is related to the measurement of the term "organizational culture", therefore interpretation of survey results has limitations. Lim (1995: 20) while mentioning studies which appear to assume the presence of a "strong" culture as a positive influence on organizational performance, points out that this assumption does not appear to take into account the influence of subcultures, hence remains faulty.

\section{Conclusions}

A great amount of discussion has taken place regarding organizational culture as a concept, though without much consensus. The reason for this is the extended scope of the concept in reality. Organizational culture represents not only many visible characteristics such as layout of corporate headquarter, office design and employee attire but also values, norms, hypotheses, ceremonies, rituals, customs, stories, myths, symbols, language and heroes that shape 
attitude, communication and behavior of employees. In this context founders, managers, and employees have a significant impact on the building of organizational culture while exogenous factors also have a certain impact on the process. Hence, each organization would have a distinctive culture of its own.

Organizational culture helps build shared values and unified efforts among employees, hence contributing to achieving the organization's objectives. Employees would know the objectives of the organization, how to reach them, what tasks and responsibilities and how they should be executed and they behave accordingly. Hence, the organization would achieve performance targets.

Organizational performance is widely influenced by organizational culture and it can be evaluated through use of several criteria. Models and approaches developed related to the concept of organization performance as well as existence of numerous criteria, making it difficult to evaluate the performance of an organization. To give an example, the question of what to consider in evaluation, achieving the objectives or tools and strategies that will help achieve the objectives, likewise the question of what to include in the model, financial or non-financial criteria, have been much discussed in the literature.

Significant research in the literature has focused on the relationship between organizational culture and performance, hence causing discussions about the criteria for the evaluation of performance. Research has demonstrated that organizational culture has an impact on evaluated performance.

It should be noted that the type of the analysis - cross-sectional or longitudinal- to be employed in performance evaluation is of high significance. In other words, while some researchers evaluated the impact of organizational culture on organizational performance over a certain time period, some others argued that abstract values organizational culture represents could not be evaluated over a certain period of time and suggested that they should be observed over long periods of time. The same question also applies to the organizational culture dimensions. Which dimensions would be employed in order to measure the impact organizational culture has on performance?

In a nutshell, both features represented by organizational culture and scope of performance continue to be controversial issues in research.

In recent years, acceleration of globalization, increasing competition, and developments in information and communication technologies added new concepts such as knowledge and innovation to organizational culture. Therefore, it has become crucial to consider the impact of these concepts in performance evaluation. Knowledge has become the most valuable resource for firms. Innovation is a significant strategy contributing to knowledge management. Therefore, measuring the impact of the concept of organizational culture which also includes innovation and knowledge management on organizational performance, which is also affected by these concepts, should be the subject matter of future research.

\section{References}

Aidla, A. and M. Vadi (2007). Relationship between organizational culture and performance in Estonian Schools with regard to their size and location. Baltic Journal of Economics, 7(1), 3-17.

Aluko, M.A.O. (2003). The impact of culture on organizational performance in selected textile firms in Nigeria. Nordic Journal of African Studies, 12 (2), 164-179.

Arslan, N.T. (2004). Örgütsel Performansı Belirleyici Bir Etmen Olarak Örgüt Kültürü ve İklimi Hakkında Bir Değerlendirme. Süleyman Demirel Üniversitesi, İktisadi ve İdari Bilimler Fakültesi, Vol. 4, No: 1, 203-228.

Barutcugil, I. (2002). Performans Yönetimi, Kariyer Yayıncıllk, İstanbul.

Chen, Chuan-Jen and Jing-Wen Huang (2009). Strategic human resource practices and innovation performance -The mediating role of knowledge management capacity. Journal of Business Research, 62, 104-114.

Corbett, L. M. and K. N. Rastrick (2000). Quality performance and organizational culture. International Journal of Quality\&Reliability Management, Vol. 17, No: 1, 14-26. 
Cetin, M. (2004). Örgüt Kültürü ve Örgütsel Bağlılık, Nobel Yayın Dağıtım, Ankara.

Daulatram, B. L. (2003). Organizational culture and job satisfaction. The Journal of Business\&Industrial Marketing, Vol. 18, No: 2/3, 219-236.

de Hilal, A. V., U. Wetzel and V. Ferreira (2009). Organizational culture and performance: a Brazilian case. Management Research News, Vol. 32, No: 2, 99-119.

Eren, E. (2010). Örgütsel Davranış ve Yönetim Psikolojisi, 12. Baskı, İstanbul.

Fletcher, B. and F. Jones (1992). Measuring Organizational Culture: The Cultural Audit. Managerial Auditing Journal, 7 (6), 30-36.

Guclu, N. (2003), Örgüt Kültürü. Kirgızistan Manas Üniversitesi, Sosyal Bilimler Dergisi, 6, 147-159.

Hofstede, G., B. Neuijen, D. D. Ohayv and G. Sanders (1990). Measuring Organizational Cultures: A Qualitative and Quantitative Study across Twenty Cases. Administrative Science Quarterly, 35, 286-316.

Iscan, O. F. and M. K. Timuroglu (2007). Örgüt Kültürünün İş Tatmini Üzerindeki Etkisi ve Bir Uygulama. İktisadi ve İdari Bilimler Dergisi, Vol. 21, No: 1, 119-135.

Jayaram, J., C. Droge and S. K. Vickery (1999). The impact of human resource management practices on manufacturing performance. Journal of Operations Management, 18, 1-20.

Karayalcin, E. (2009). Bankacıllk Sektöründe Örgüt Kültürü, Liderlik ve Firma (Şube) Performansı İlişkisi, Yüksek Lisans Tezi, Kadir Has Üniversitesi, Sosyal Bilimler Enstitüsü.

Kilic, I. C. (2009). Organizasyonel Kültürün İş Performansına Etkisi ve Niğde İlinde Bir Uygulama, Yüksek Lisans Tezi, Niğde Üniversitesi, Sosyal Bilimler Enstitüsü.

Kilic, T. (2007). Örgüt Kültürü, Örgütsel Hafıza Arasındaki İlişkiler ve Firma Performansı Üzerine Etkileri, Yüksek Lisans Tezi, Kadir Has Üniversitesi, Sosyal Bilimler Enstitüsü.

Lee, S. K. J. and K. Yu (2004). Corporate culture and organizational performance. Journal of Managerial Psychology, Vol. 19, No: 4, 340-359.

Lim, B. (1995). Examining the organizational culture and organizational performance link. Leadership\&Organization Development Journal, Vol. 16 No: 5, 16-21.

Ogbonna, E. and L. C. Harris (2000). Leadership style, organizational culture and performance: empirical evidence from UK companies. International Journal of Human Resource Management, 11(4), 766-788.

Onken, M. H. (1999). Temporal elements of organizational culture and impact on firm performance. Journal of Managerial Psychology, Vol. 14, No: 3/4, 231-243.

Ozen Kutanis, R. (2010). Örgüt Kültürü, Ders Notları, İstanbul.

Ozen Kutanis, R. and M. Mesci (2010). Örgüt Kültürünün İşgörenlerin İş Tatminine ve Örgütsel Performansa Etkisi: Beş Yıldızlı Bir Otel İşletmesinde Örnek Olay Çalışması. Seyahat ve Otel Işsletmeciliği Dergisi, Year: 7, No: 4, 40-49.

Prajogo, D. I. and C. M. McDermott (2011). The relationship between multidimensional organizational culture and performance. International Journal of Operation\&Production Management, Vol. 31, No: 7, 712-735.

Robbins, S. P. and T. A. Judge (2011). Organizational Behavior, 14th Edition, Pearson Education, Inc., New Jersey.

Schein, E. H. (2002). Örgütsel Kültür. (Translated) Atilla Akbaba, Dokuz Eylül Üniversitesi, Sosyal Bilimler Enstitüsü Dergisi, Vol. 4, No: 3, 1-32.

Sahin, A. (2010). Örgüt Kültürü-Yönetim İlişkisi ve Yönetsel Etkinlik. Maliye Dergisi, No: 159, 21-35. 
Trompenaars, F. and C. Hampden-Turner (1998). Riding the Waves of Culture, Understanding Diversity in Global Business, 2th Edition, McGraw-Hill.

Tseng, Shu-Mei (2010). The correlation between organizational culture and knowledge conversion on corporate performance. Journal of Knowledge Management, Vol. 14, No: 2, 269-284.

Uzun, D. (2007). Örgüt Kültürünün Bilgi Yönetimi Sürecine ve Örgütsel Performansa Etkisi: Beş Yıldızlı Otel İşletmelerinde Bir Uygulama, Doktora Tezi, Dokuz Eylül Üniversitesi, Sosyal Bilimler Enstitüsü, İzmir.

Yuksel, A. H. (2002). Örgüt Kültürünün Performans Üzerine Etkisi ve Aracı Kurum Personeli Üzerine Bir Araştırma, Yüksek Lisans Tezi, İ.Ü. İşletme Anabilim Dalı, İstanbul. 